\title{
STUDIES CONCERNING THE INFLUENCE OF ARSENICAL PREPARATIONS ON CUTANEOUS TESTS
}

\author{
ALBERT STRICKLER, M.D. \\ Clinical Professor of Dermatology and Syphilology, Temple University, \\ Department of Medicine \\ PHILADELPHIA
}

For a long time the medical profession has felt the urgent need of a simple and certain diagnostic test for syphilis. The wide distribution of syphilis, the fact that syphilis can and does simulate many other diseases, and the fact that even experts are at times baffled in their diagnosis, have emphasized the necessity for a simple and certain diagnostic test for this disease.

After von Pirquet announced his reaction for tuberculosis, many investigators, among them Finger, Wolff-Eisner, Nicholas and others, attempted to obtain a specific reaction by applying extracts of syphilitic tissues to the skin of syphilitic patients. Neisser and Meirowsky had found that normal hepatic extract could not only occasionally give a similar exanthematic result as syphilitic extract, but that the test might also give a positive result in patients in whom there was no reason to suppose the existence of syphilis. In spite of some rather encouraging results, the majority of results from this method proved contradictory and disappointing. Both Neisser and von Pirquet expressed the hope and belief that a specific skin test for syphilis could be obtained by employing the extract of Spirochaeta pallida free from tissue constituents.

With Noguchi's cultivation of Spirochaeta pallida, a new stimulus was given to these investigations. In 1911, Noguchi brought out "luetin" a sterile extract of the spirochete unadulterated by any tissue constituents. Luetin was injected intracutaneously in a dose of 0.07 c.c. diluted with salt solution, or 0.035 c.c. undiluted. The skin of the arm was suggested as the site of injection. In this investigation the luetin of Parke, Davis and Company was employed. The dose was 0.07 c.c. injected intracutaneously into the upper arm. We quote from a personal letter sent us by Parke, Davis and Company which details the method they followed in manufacturing their luetin:

"Pure cultures were allowed to grow for periods of six, twelve, twenty-four and fifty days at $37 \mathrm{C}$. under anaerobic conditions. One was cultivated in ascitic fluid containing a piece of sterile placenta and the other in ascitic fluid agar also containing placenta. The lower 
portion of each solid culture in which a dense growth had occurred was cut out and the tissue removed. The agar columns which contained innumerable spirochetes were then carefully ground in a sterile mortar. The resulting thick paste was gradually diluted by adding, little by little, the fluid cultures which also contained an enormous mass of the pure organisms. The dilution was continued until the emulsion became perfectly liquid. The preparation was next heated to $60 \mathrm{C}$. for sixty minutes in a water bath and then 0.5 per cent. phenol was added. When examined under a dark-field microscope, 40 to 100 dead Spirochaeta pallida per field could be seen."

\section{INTERPRETATION OF REACTION}

In our investigation we found that a number of our patients, after receiving luetin injections, showed a small papule devoid of erythema. This was noted twenty-four and forty-eight hours after the test was made, but disappeared subsequently. This type of reaction we considered of negative value.

Two types of positive reactions were observed: (a) Papular: This consisted of a large, red, indurated papule which made its appearance in from twenty-four to forty-eight hours after injection, usually attended with a surrounding erythema. In the great majority of our subjects this reaction disappeared at the end of a week. (b) Pustular: This type of reaction began as the papular, except that the lesions became edematous looking and at times associated with the development of miliary vesicles. The lesion soon became pustular with crusting and, at times, very slight scar formation. In several instances of this type of reaction the pustular condition persisted for three weeks before healing.

Our investigation had for its aim the determination of these facts:

1. What would be the influence of a repetition of the luetin test and the tuberculin (von Pirquet) test?

2. What would be the influence of intravenous injections of arsphenamin on the luetin test and the tuberculin (von Pirquet) test?

3. What would be the influence of intravenous injections of cacodylate of soda on the luetin test and the tuberculin (von Pirquet) test?

THE INFLUENCE OF A REPETITION OF THE LUETIN TEST

For a study of this problem we selected fourteen patients from the dermatologic dispensary of the Jefferson Hospital. The patients suffered from various skin diseases, principally eczema and acne vulgaris. At least two Wassermann tests were made on each patient, both of which had to be negative before they were selected as eligible for this investigation.

Table 1 shows that in every case the first luetin test was negative, that in the repetition of the test there were three instances out of four- 


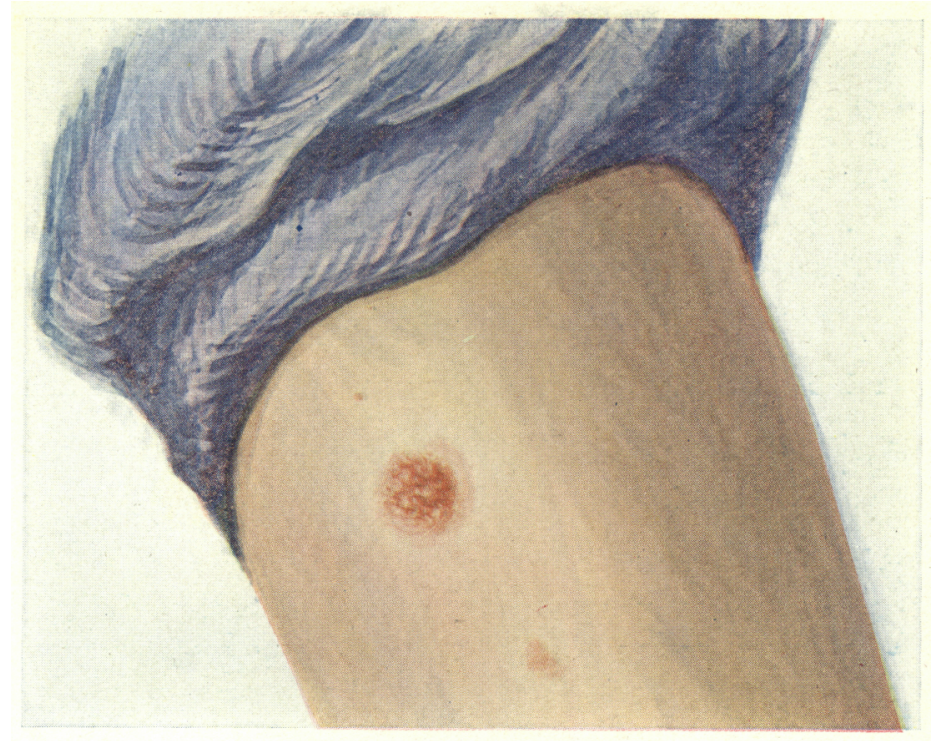

A. $1 \mathrm{HI}$. P.; sccond luctin test strongly positive-pustular type obtained after three intravenous injections of arsphenamin. The first luetin test macle before the injections were given was negative.

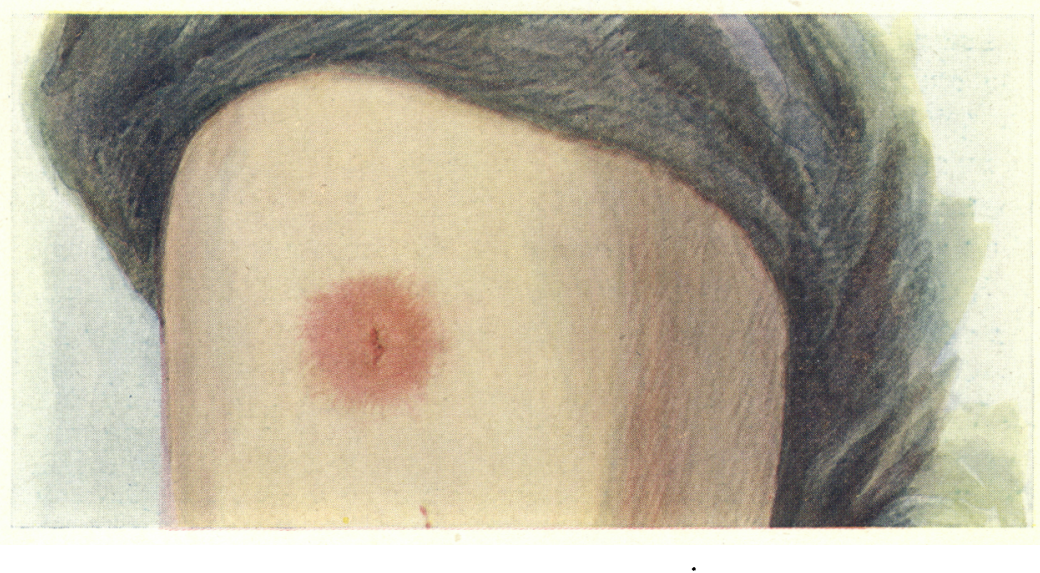

B. 2 B. C.; strongly positive tuberculin (von Pirquet) test following font intravenous injections of arsphenamin. The lesion was about the size of a fuarter of a dollar, recl and edematous, and surrouncled by a number of small resicles. The first tuberculin test made before the injections were given mas negative. 
teen in which the previous negative reaction became positive, and these positive reactions were produced in the absence of any medication. It will also be noted that in all instances but two an interval of three weeks elapsed between the first and second tests.

At this juncture it seems proper to discuss the cause or causes of these positive luetin tests produced by repetition. Among the theories which have been advanced to explain the occurrence of a positive luetin

TABLE 1.-Results of VARIOUS Tests

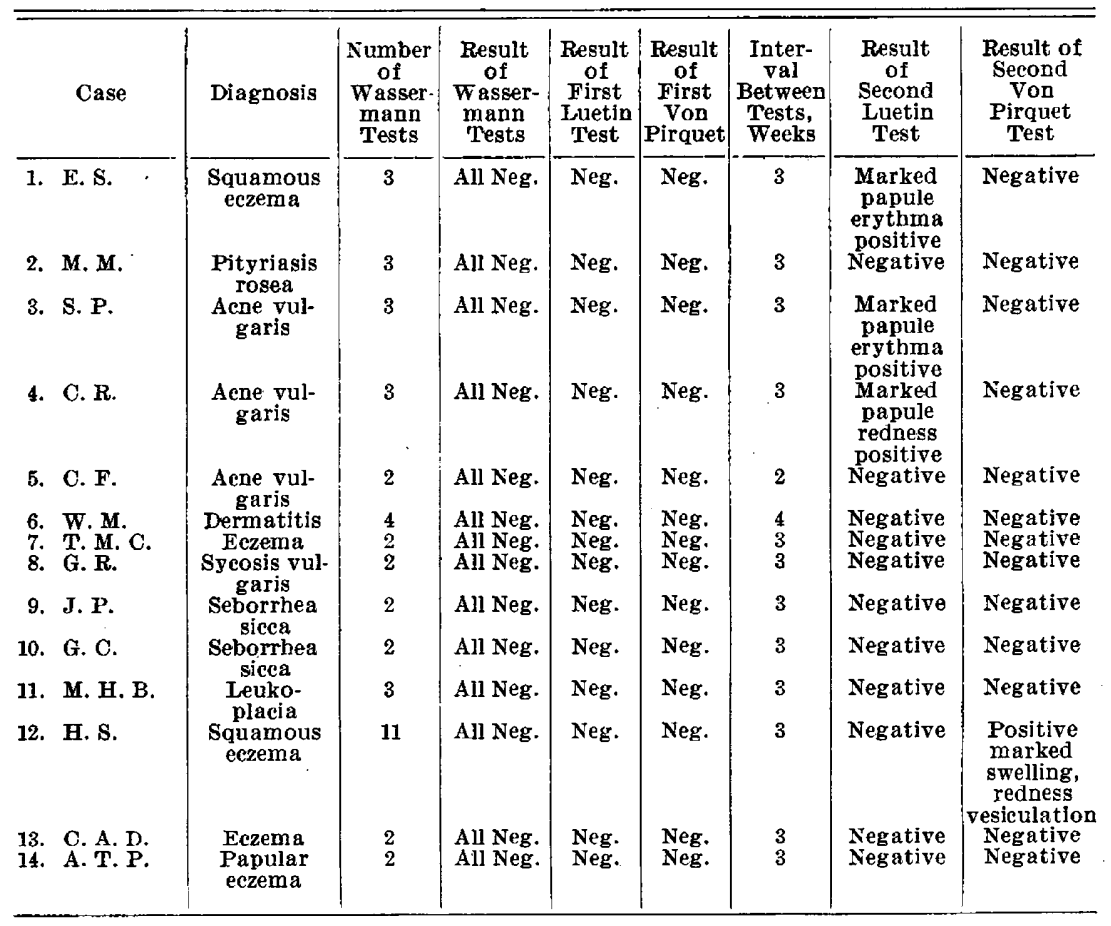

reaction in tertiary syphilis is the alleged peculiarity of the cutis of the syphilitic at that stage of the disease which Neisser termed "Umstimmung" of the skin. Can we possibly explain our positive luetin findings produced by the repetition of the luetin test on the ground that the first inoculation of dead spirochetes sensitized the skin of subjects so that the subsequent luetin tests could be capable of producing a positive result? This would appear a logical theory and would agree with the conception of the production of a positive luetin test.

\section{THE INFLUENCE OF INTRAVENOUS INJECTIONS OF ARSPHENAMIN. ON THE LUETIN TEST}

For this study we selected seventeen patients suffering from various skin affections: acne vulgaris, eczema, psoriasis and other conditions. At least two negative Wassermann reactions were necessary before 
the patients were considered eligible for this investigation. A study of this table shows that ten patients received three injections of arsphenamin, three received four injections, two received five injections and one received two injections before the luetin test was repeated.

These injections were given at weekly intervals, the average dose being $0.4 \mathrm{gm}$. given intravenously. It will be noticed that of this series nine patients gave a positive luetin reaction on repetition, and eight responded negatively to a repetition of the luetin test.

TABLE 2.-Results of Arsphenamin on Luetin Tests

\begin{tabular}{|c|c|c|c|c|c|c|}
\hline Case & Diagnosis & $\begin{array}{l}\text { Wasser- } \\
\text { mann } \\
\text { Report }\end{array}$ & $\begin{array}{c}\text { Number } \\
\text { of } \\
\text { Wasser- } \\
\text { mann } \\
\text { Tests }\end{array}$ & $\begin{array}{c}\text { Result of } \\
\text { First } \\
\text { Luetin } \\
\text { Test }\end{array}$ & $\begin{array}{l}\text { Number } \\
\text { of Ars- } \\
\text { phena- } \\
\text { min } \\
\text { Injec- } \\
\text { tions }\end{array}$ & $\begin{array}{l}\text { Results of Subsequent } \\
\quad \text { Luetin Tests }\end{array}$ \\
\hline 1. B. C. & Purpura & Negative & 2 & Negative & 5 & $\begin{array}{l}\text { Luetin test, papule and } \\
\text { erythema positive }\end{array}$ \\
\hline 2. I. C. & Acne vulgaris & Negative & 2 & Negative & 3 & Negative \\
\hline 3. W. H. & Urticaria & Negative & 2 & Negative & 5 & Negative \\
\hline 5. F. H. & $\begin{array}{l}\text { Acne vulgaris } \\
\text { Acne vulgaris }\end{array}$ & $\begin{array}{l}\text { Negative } \\
\text { Negative }\end{array}$ & $\begin{array}{l}2 \\
2\end{array}$ & $\begin{array}{l}\text { Negative } \\
\text { Negative }\end{array}$ & $\begin{array}{l}4 \\
5\end{array}$ & $\begin{array}{l}\text { Negative papule and } \\
\text { Positive, }\end{array}$ \\
\hline $\begin{array}{l}\text { 6. H. H. } \\
\text { 7. R. C. }\end{array}$ & $\begin{array}{c}\text { Urticaria } \\
\text { Acne mutilans }\end{array}$ & Negative & $\begin{array}{l}8 \\
2\end{array}$ & Negative & 3 & Negative \\
\hline 8. E. R. & Aene vulgaris & Negative & 2 & Negative & 2 & $\begin{array}{l}\text { Positive, marked papule } \\
\text { becoming pustular sec- } \\
\text { ondarily }\end{array}$ \\
\hline 9. J. D. & Pityriasis rosea & Negative & 2 & Negative & 5 & $\begin{array}{l}\text { Slightly positive papule } \\
\text { with inflitration and } \\
\text { slight erythema }\end{array}$ \\
\hline 10. O. D. & Acne vulgaris & Negative & 2 & Negative & 4 & $\begin{array}{c}\text { Positive, papule with } \\
\text { erythema }\end{array}$ \\
\hline 11. G. L. & Acne vulgaris & Negative & 9 & Negative & 3 & Negative \\
\hline 12. H. L. & Furunculosis & Negative & 2 & Negative & 3 & $\begin{array}{c}\text { Positive, papule with } \\
\text { erythema }\end{array}$ \\
\hline 13. G. S. & Folliculitis & Negative & 2 & Negative & 3 & $\begin{array}{l}\text { Slightly positive papule } \\
\text { with slight erythema }\end{array}$ \\
\hline 14. H. P. & Eczema & Negative & 9 & Negative & 3 & $\begin{array}{l}\text { Markedly positive pustu- } \\
\text { lar type of reaction, see } \\
\text { illustrations }\end{array}$ \\
\hline 15. H. R. & $\begin{array}{c}\text { Dermatitis } \\
\text { herpetiformis }\end{array}$ & Negative & 2 & Negative & 3 & Negative \\
\hline 16. B. T. & $\begin{array}{l}\text { Prurigo nodu- } \\
\text { laris }\end{array}$ & Negative & 2 & Negative & 3 & $\begin{array}{l}\text { Markedly positive pustu- } \\
\text { lar type }\end{array}$ \\
\hline 17. R. K. & Psoriasis & Negative & 2 & Negative & 3 & Negative \\
\hline
\end{tabular}

THE INFLUENCE OF CACODYLATE OF SODA, INTRAVENOUSLY ADMINISTERED, ON THE LUETIN TEST

In this series we employed five patients, who fulfilled the same requirements as those in the previous series. These patients received 10 c.c. of cacodylate of soda, intravenously, this solution containing the same amount of arsenic as $.0 .6 \mathrm{gm}$. of arsphenamin. It will be noted that of this series only one patient presented a slightly positive reaction. It is to be regretted that this series. was small. In addition we performed the luetin test on a series of seven patients who had received from ten to twenty-one injecţions of cacodylate intravenously at weekly intervals. Of this series one patient presented a marked reaction of the papular type, and in the other instance the papular 
reaction was positive but not marked. It is our impression that this last experiment seems to prove the influence of cacodylate of soda on the luetin test.

TABLE 3.-Influence of Cacodylate of Soda on the Luetin Test

\begin{tabular}{|c|c|c|c|c|c|c|}
\hline Case & Diagnosis & $\begin{array}{l}\text { Wasser- } \\
\text { mann } \\
\text { Report }\end{array}$ & $\begin{array}{l}\text { Number } \\
\text { of } \\
\text { Wasser- } \\
\text { mann } \\
\text { T'ests }\end{array}$ & $\begin{array}{c}\text { Result of } \\
\text { First } \\
\text { Luetin } \\
\text { Test }\end{array}$ & $\begin{array}{l}\text { Number } \\
\text { of Injec- } \\
\text { tions } \\
\text { of Caco- } \\
\text { dylate } \\
\text { of Soda }\end{array}$ & $\begin{array}{c}\text { Results of Subsequent } \\
\text { Luetin 'Tests }\end{array}$ \\
\hline $\begin{array}{l}\text { 1. H. N. } \\
\text { 2. A. S. } \\
\text { 3. E. G. } \\
\text { 4. T. J. } \\
\text { 5. C. D. }\end{array}$ & $\begin{array}{c}\text { Lichen planus } \\
\text { Vesicular eczema } \\
\text { Fczema } \\
\text { Eczema } \\
\text { Sycosis vulgaris }\end{array}$ & $\begin{array}{l}\text { Negative } \\
\text { Negative } \\
\text { Negative } \\
\text { Negative } \\
\text { Negative }\end{array}$ & $\begin{array}{l}2 \\
2 \\
2 \\
3 \\
\\
3\end{array}$ & $\begin{array}{l}\text { Negative } \\
\text { Negative } \\
\text { Negative } \\
\text { Negative } \\
\text { Negative }\end{array}$ & $\begin{array}{l}2 \\
4 \\
3 \\
3 \\
1\end{array}$ & $\begin{array}{l}\text { Negative } \\
\text { Negative } \\
\text { Negative } \\
\text { Slightly positive, papule } \\
\text { and redness } \\
\text { Negative }\end{array}$ \\
\hline
\end{tabular}

INFLUENCE OF IODIDS AND BROMIDS ON LUETIN TEST

I shall review in brief the influence of iodids and bromids on the luetin test in comparison with the influence of arsenical preparations given intravenously on the same test.

It was shown by Sherrick, and confirmed by others, that nonsyphilitic persons taking bromids or iodids at the time that this skin test is made, or while these drigs are still in the body fluids, may yield well marked nonspecific reactions which may be interpreted as positive luetin reactions. N. C. Borberg, in an exhaustive study of the mechanism of this phenomenon, concludes that the administration of iodin salts produces "Umstimmung" of the skin which is apparent by an increase of the inflammatory reaction around bacterial deposits.

We feel that our study warrants us in stating that arsenic probably produces the same susceptibility of the skin in nonsyphilitic persons, so that the administration of arsphenamin may cause the production of a positive luetin test in nonsyphilitics. In our series we have shown that while the repetition of the luetin test yielded 21 per cent. positive reactions, the arsphenamin series yielded 53 per cent. positive reactions, which is highly suggestive if not conclusive.

It is an obvious step to compare the depot of luetin in the skin with that of the spirochete depot in papules and gummas, and to regard the reaction of the arsenic and also iodin imbibed tissues around the former as a picture of what may be supposed to take place around the latter. We have therefore what we may call an unspecific Herxheimer reaction-an acute aseptic inflammation.

\section{TUBERCULIN INVESTIGATIONS}

The Infuence of the Repetition of the Tuberculin Test.-In this investigation we also studied the repetition of the tuberculin (von Pirquet) method. Table 1 shows that the tuberculin test in the four- 
teen subjects proved negative, while the repetition resulted in one positive result among this series of fourteen patients.

Infuence of Intravenous Injections of Arsphenamin on Tuberculin Test.-We then selected another series of ten patients on whom at least two Wassermann tests had been performed and performed the tuberculin (von Pirquet) test on them. We then administered arsphenamin intravenously in a dose of $0.5 \mathrm{gm}$. at weekly intervals. After our patients had received a certain number of these injections, we again performed the tuberculin (von Pirquet) method with the results shown in Table 4.

Table 4.-Infllence of Arsphenamin on Tuberculin Tests

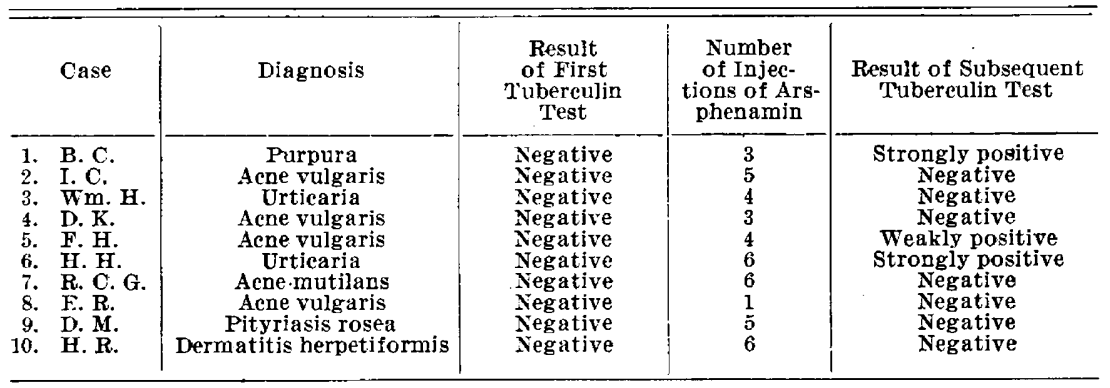

Table 4 shows that except in one instance in which only one injection of arsphenamin was given, the number of injections of arsphenamin varied from three to six; also that of this series of ten patients, two patients showed well marked reactions with distinct swelling, erythema and miliary vesicles, this phenomenon lasting about five or six days before subsiding. In all our work the tuberculin of the H. K. Mulford Company was utilized and in each instance of the test a glycerin bouillon control was made.

The Influence of Intravenous Injections of Cacodylate of Soda on the Tuberculin Test.-In five instances we studied the effect of intravenous injections of cacodylate of soda on the tuberculin (von Pirquet) test. In one instance in which the patient had been gassed in army service, the first as well as the subsequent tuberculin test made after two intravenous injections of cacodylate of soda, proved positive. In the four other instances the first tuberculin (von Pirquet) tests were negative and the subsequent von Pirquet tests after two to four intravenous injections of cacodylate of soda also were negative. Also, without doing a preliminary tuberculin test we performed a von Pirquet test on seven patients, each of whom had received intravenous injections of cacodylate of soda varying from ten to twenty treatments, and in every case but one the tuberculin tests were negative. That one showed a weak positive von Pirquet reaction. 
From this study we may conclude that arsphenamin injections are capable of sensitizing the skin to such an extent that it can change the mechanism of the tuberculin (von Pirquet) test so that a positive result can be obtained.

It would appear to us that the arsphenamin acted with the tuberculin test in the same way as the arsphenamin acted with the luetin test.

N. C. Borberg, in his study of the luetin test and the effects of the iodin preparations on it, also tested the effects of the iodin preparations on the tuberculin test, and he found that the iodids were capable of influencing the tuberculin (von Pirquet) test, producing at the point of inoculation a sort of local Herxheimer reaction; hence it would appear that arsphenamin acts in the same way as the iodids both in the luetin and tuberculin tests.

It may be possible that this "Umstimmung" of the skin produced by arsphenamin may account for the influence which Stokes found arsphenamin possesses in the treatment of various forms of tuberculosis of the skin.

In an investigation which we are conducting it appears that neither the intravenous injections of arsphenamin nor that of cacodylate of soda have any influence on the anaphylactic food tests made either by the intracutaneous or the scratch methods.

\section{CONCLUSIONS}

As a result of our studies we may conclude:

1. The repetition of a luetin test in nonsyphilitic patients is capable of producing positive luetin tests in about 21 per cent. of our subjects.

2. The intravenous administration of arsphenamin apparently stimulates the production of a luetin test in nonsyphilitic patients, and in our series we were able to produce 53 per cent. positive luetin tests following this form of intravenous specific therapy.

3. In our experience the intravenous administration of cacodylate of soda acts in the same manner as arsphenamin, only more feebly.

4. The repetition of the tuberculin (von Pirquet) test may produce a positive finding, but very infrequently, occurring only once in our series of fourteen subjects.

5. The intravenous administration of arsphenamin is capable of producing a positive tuberculin (von Pirquet) test, previously negative. This occurred in three instances in our series of ten patients.

6. The anaphylactic food test made by either the endermic or scratch method does not seem to be influenced by the intravenous administration of either arsphenamin or cacodylate of soda. Our investigation of this phase of the problem is, however, not yet complete.

7. We are now engaged in studying the effect of the arsenicals given by mouth on the luetin, tuberculin and anaphylactic food tests.

1408 Spruce Street. 